\title{
EDUCAÇÃO AMBIENTAL: ESTUDO DE CASO EM DOIS COLÉGIOS ESTADUAIS DA CIDADE DE SARANDI (PR)
}

\author{
Ana Carla Fernandes Gasques ${ }^{1}$ \\ Cristhiane Michiko Passos Okawa² \\ Jordana Dorca dos Santos ${ }^{3}$ \\ Elisabet Gabrieli Fernandes Gasques ${ }^{4}$ \\ Francielle Delabio ${ }^{5}$
}

Resumo: A Educação Ambiental surgiu por meio de uma sugestão de solução para as necessidades que não estavam sendo satisfeitas por completo pela educação formal. A partir do exposto, o presente artigo tem por objetivo geral realizar um estudo acerca da prática de ações de Educação Ambiental em dois colégios estaduais na cidade de Sarandi (PR). Para tal a metodologia foi desenvolvida a partir de pesquisa exploratória, bem como um estudo de caso em dois colégios estaduais por meio de questionários. Através de questionários elaborados para alunos e professores com perguntas direcionadas à aplicação da Educação Ambiental nas escolas estaduais, foi possível verificar que, mesmo sendo um tema abordado pelos professores durante quase todo o ano letivo, ainda falta o aperfeiçoamento e capacitação por parte dos professores a fim de auxiliar e aprimorar a aplicação da Educação Ambiental. Por fim, é importante considerar que a EA não deve ser desenvolvida apenas com a finalidade de acrescentar conteúdo na grade curricular, mas sim, dando um enfoque no conhecimento crítico e aplicado, despertando nos alunos uma sensibilização à transformação social e preservação ambiental.

Palavras-chave: Educação Ambiental; Desenvolvimento Sustentável; Gestão Ambiental.

\footnotetext{
1Universidade Estadual de Maringá. E-mail: anacarlafgasques@gmail.com

2 Universidade Estadual de Maringá E-mail: crisokawa@gmail.com

3Universidade Estadual do Paraná. E-mail: jordanadorca@gmail.com.

${ }^{4}$ Universidade Estadual do Oeste do Paraná. E-mail: elisabet.gasques@gmail.com

${ }^{5}$ Universidade Estadual de Maringá. E-mail: francielledelabio@gmail.com
} 


\section{Introdução}

A questão ambiental atual revela, em um primeiro momento, uma problemática da própria sociedade: não é o ambiente que se apresenta em desacordo, é a civilização. A relação entre o ambiente e a educação assume um papel cada vez mais desafiador demandando a emergência de novos saberes para apreender processos sociais que se complicam e riscos ambientais que se intensificam (PIOVESANA, 2011).

A vivência em grupo proporciona novas formas de pensamento, viabilizando uma visão de mundo mais ampliada, percebendo assim, as várias possibilidades de lidar com um problema ou desenvolver uma solução. Assim, para que o processo de Educação Ambiental seja efetivo é necessário que a escola se proponha a trabalhar com atitudes, com formação de valores, com o ensino e a aprendizagem de habilidades e procedimentos, sendo, portanto, um grande desafio para a educação (SANTOS, 2009).

A Educação Ambiental foi implantada na década de 1980, pela Lei no 6.938 de 1981 através da Política Nacional de Meio Ambiente (PNMA). Segundo a Constituição Brasileira de 1988, artigo 225, $1^{\circ}$ parágrafo, inciso VI, cabe ao Poder Público promover a Educação Ambiental em todos os níveis de ensino e a conscientização pública para a preservação do meio ambiente (BRASIL, 1990). Esta política define Educação Ambiental como sendo o conjunto dos processos por meio dos quais o indivíduo e a coletividade constroem valores sociais, conhecimentos e competências voltadas para a conservação do meio ambiente e sua sustentabilidade.

Frente aos graves problemas ambientais que nos atingem em vários níveis, torna-se cada vez mais necessário o desenvolvimento de uma educação voltada ao ambiente bem como a prática desta educação, caracterizadas pela multiplicidade de fatores existentes. Dessa forma, considerando os problemas ambientais atuais, a Educação Ambiental passa a ser uma das estratégias significativas na construção de uma nova mentalidade de desenvolvimento com a utilização sustentável dos recursos naturais, priorizando o crescimento com equidade social e o equilíbrio ecológico.

Assim, o presente artigo tem por objetivo geral realizar um estudo acerca da prática de ações de Educação Ambiental em dois colégios estaduais na cidade de Sarandi-PR.

\section{Metodologia}

A metodologia é caracterizada como pesquisa exploratória e estudo de caso. Para Gil (2002) e Vieira (2002) a pesquisa exploratória tem por objetivo favorecer uma maior intimidade com o tema, tornando-o mais claro além de propor ao pesquisador maior intimidade com o assunto, possibilitando a compreensão do problema, caracteriza-se também como descritiva, pois os fatos serão observados, analisados, registrados, classificados e interpretados, sem que o pesquisador interfira nele. 
É tida como estudo de caso, pois para Yin (2010, p. 39), é "uma investigação empírica que investiga um fenômeno contemporâneo em profundidade e em seu contexto de vida real, especialmente quando os limites entre o fenômeno e o contexto não são claramente evidentes". Para realização do estudo de caso utilizaram-se dois questionários Apêndice $A$ e $B$, os quais foram aplicados a professores e alunos de dois Colégios Estaduais do Ensino Fundamental II localizados na cidade de Sarandi - PR, no decorrer dos meses de setembro a outubro de 2015. A primeira amostra foi composta por alunos do $6^{\circ}$ ao $9^{\circ}$ ano, sendo que cada turma foi representada por 10 alunos, totalizando 40 alunos, escolhidos aleatoriamente e a segunda amostra foi composta por 10 professores de cada colégio, totalizando 20 professores.

A última etapa consistiu na análise dos dados e informações obtidas a fim de analisar e comparar a opinião dos alunos e dos professores acerca da Educação Ambiental desenvolvida nos Colégios, ou da ausência desta.

\section{Resultados e Discussões}

Os dados obtidos nos questionários foram analisados dividindo-se em alunos e professores e as respostas obtidas em cada questão foram comparadas entre os dois colégios analisados.

\section{Análise das respostas fornecidas pelos alunos}

A primeira pergunta do questionário fazia referência acerca da importância de se tratar acerca de meio ambiente. Nos dois Colégios analisados, todos os alunos responderam que sim, que consideram importante falar sobre meio ambiente. Segundo Dias (1994) a Educação Ambiental deve ser trabalhada, pois se caracteriza por incorporar as dimensões sociais, políticas, econômicas, culturais, ecológicas e éticas, o que significa que ao tratar de qualquer problema ambiental, devem-se considerar todas as dimensões.

Apesar de todos responderem que consideram importante tratar acerca desta temática, foi possível observar que nem todos os professores, segundo os alunos, trabalham a mesma. Em ambos os colégios mais de $90 \%$ dos alunos responderam que a EA é trabalhada em alguma disciplina curricular. Para Jacobi (2003) a Educação Ambiental quando trabalhada nas disciplinas curriculares pode desenvolver propostas pedagógicas focadas na conscientização, mudança de comportamento, capacitação, capacidade de avaliação e participação dos alunos.

A segunda pergunta relaciona-se à anterior: caso a resposta na pergunta anterior fosse positiva, os alunos deveriam indicar em quais disciplinas é trabalhada a temática EA. Nos dois colégios analisados, apesar de divergências nas porcentagens constatadas (Figuras 1 e 2), verificou-se que as disciplinas que mais trabalham EA são: Português, Ciências e Geografia. 


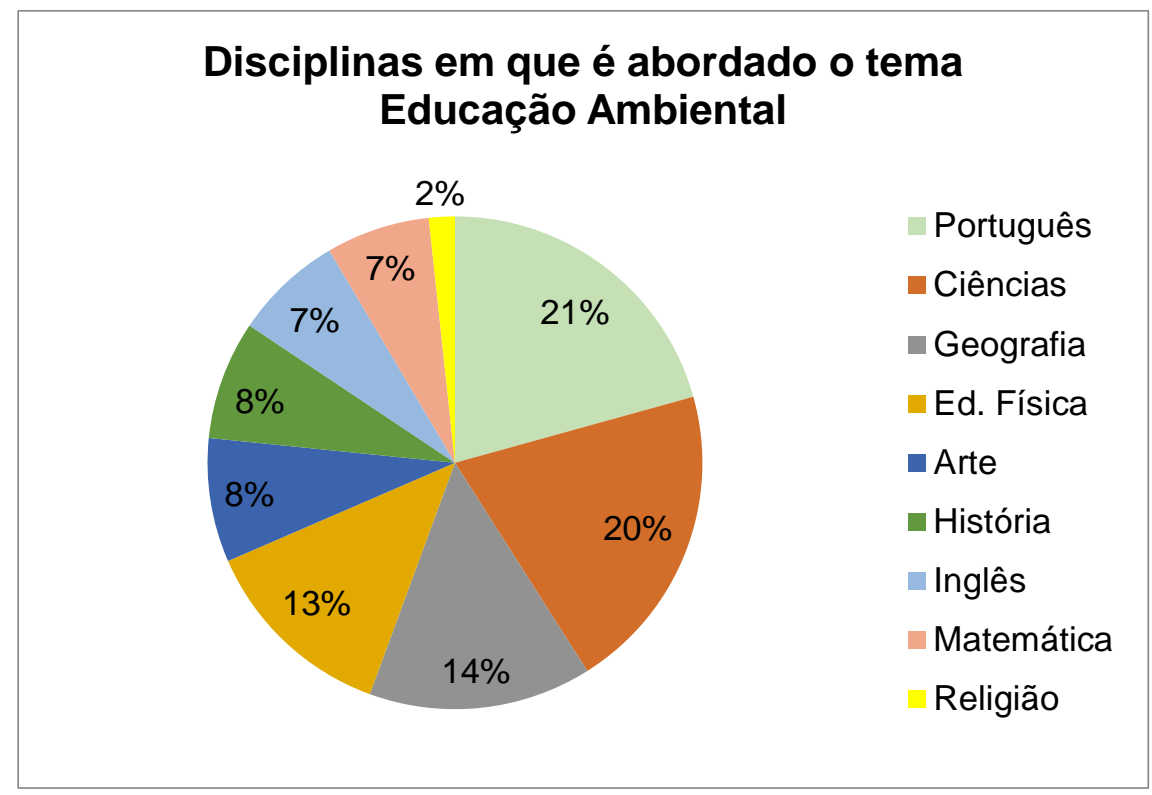

Figura 1: Disciplinas em que é abordado o tema EA no Colégio.

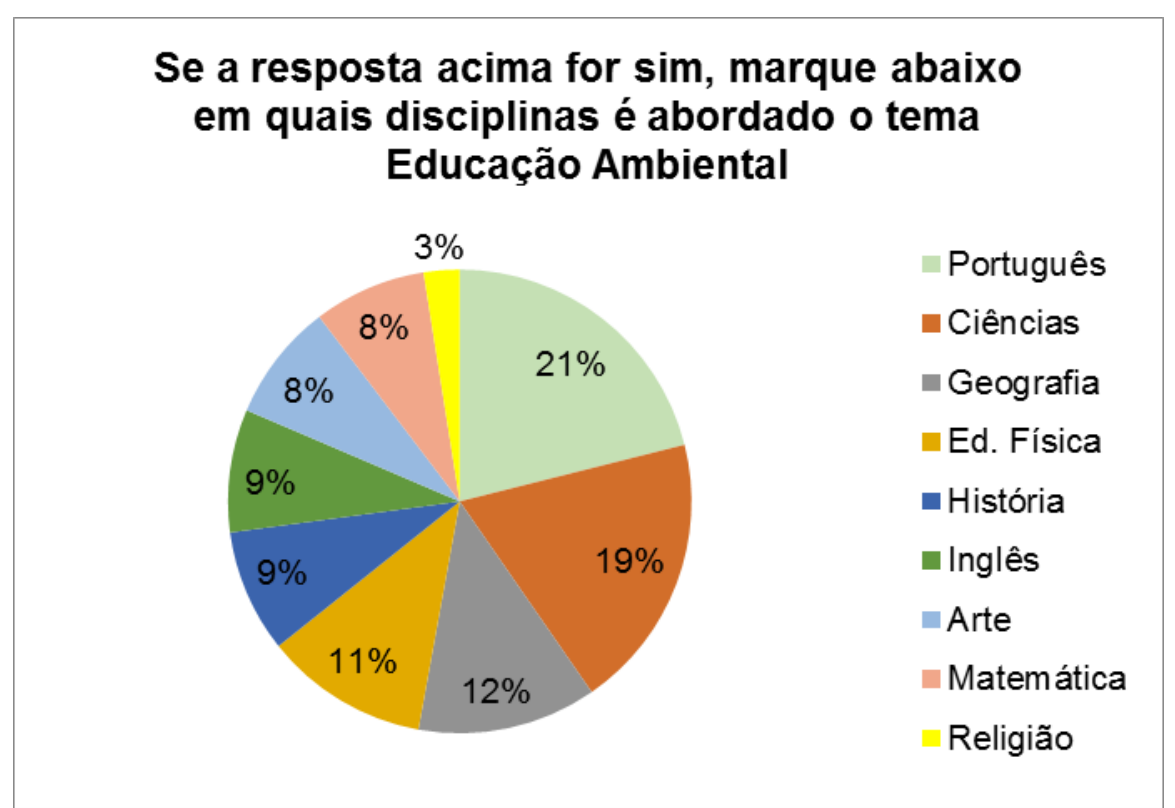

Figura 2: Disciplinas em que é abordado o tema EA no Colégio B.

Ao comparar os dados obtidos com a literatura, constatou-se que o tema meio ambiente faz parte dos temas universais e deve ser abordado nas diversas disciplinas curriculares (ARARUNA, 2009). A disciplina de Língua Portuguesa é caracterizada por adotar uma expectativa transversal dos conteúdos ministrados, possibilitando trabalhar textos dos mais variados assuntos (FERREIRA, 2013). Além disso, Reigota (2007) constatou que a temática ambiental vem sendo mais frequentemente associada às disciplinas escolares Ciências e Geografia, o que também foi constatado nos colégios analisados. 
A próxima pergunta questionou-os sobre os temas mais trabalhados da lista citada: Ecologia, Resíduos Sólidos, Água, Aquecimento Global, Desmatamento ou Outro. Nos dois colégios analisados, apesar de divergências nas porcentagens constatadas (Figuras 3 e 4), verificou-se que os assuntos mais trabalhados são: Desmatamento, Aquecimento Global e Ecologia.

\section{Quais os temas mais discutidos pelos professores quando falam sobre Educação Ambiental?}

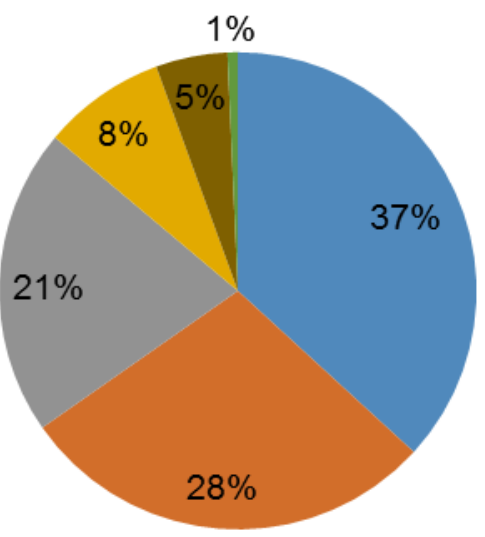

- Desmatamento

Aquecimento Global

- Ecologia

- Água

- Resíduos Sólidos

- Outro

Figura 3: Temas mais discutidos pelos professores quando falam sobre Educação Ambiental no Colégio.

\section{Quais os temas mais discutidos pelos professores quando falam sobre Educação Ambiental?}

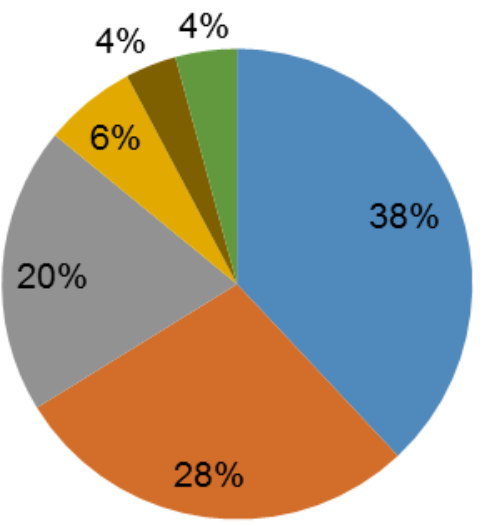

Desmatamento

- Aquecimento Global

Ecologia

- Resíduos Sólidos

- Água

- Outro

Figura 4: Temas mais discutidos pelos professores quando falam sobre Educação Ambiental no Colégio B. 
Ao analisar as respostas obtidas, no Colégio A posterior as disciplinas mais citadas, a sequência foi: Água (12\%) e Resíduos Sólidos (7\%), apenas um aluno marcou a opção "outro", porém não especificou. Enquanto no Colégio B a sequência constituiu: Resíduos Sólidos (6\%), Água (4\%) e seis alunos responderam "outro", também sem justificar, representando $4 \%$ das respostas.

Lins e Lisovski (2010, p. 12) investigaram sobre os temas de Educação Ambiental abordados pelos professores em uma escola pública de Mamborê PR e constataram que "os principias temas abordados pelos professores investigados são: preservação ambiental, resíduos sólidos, o aquecimento global e o efeito estufa". Os temas identificados pelos autores são semelhantes aos mencionados na presente pesquisa, pois fazem parte dos temas mais debatidos acerca da questão ambiental na atualidade.

A próxima pergunta fez referência ao desenvolvimento de atividades práticas. No Colégio A $51 \%$ dos alunos entrevistados responderam que seus professores já desenvolveram alguma atividade prática voltada para a Educação Ambiental, enquanto no Colégio B essa porcentagem foi maior, sendo representada por 71\%. Para Fadanni e Massola (2010) implantar atividades práticas para a introdução da temática Educação Ambiental é imprescindível, através do desenvolvimento de atividades educativas na qual os alunos, em conjunto com os professores, sejam capazes de assimilar melhor o conteúdo proposto, bem como relacioná-lo com situações do seu cotidiano. Assim, mostra-se importante a realização de atividades práticas para desenvolver o tema EA nas escolas.

A sexta pergunta envolveu a frequência com a qual o tema EA é trabalhado, se apenas na Semana do Meio Ambiente, no decorrer do ano letivo ou, ainda, se esta não é trabalhada. Apesar da divergência nas respostas, nos dois colégios analisados, segundo os alunos, o referido tema é trabalhado no decorrer de todo o ano letivo. Sobre a frequência de se trabalhar EA, Narcizo (2009) alega que existem muitas dificuldades no que se refere ao desenvolvimento do tema e a sensibilização do todo escolar, ao processo de implantar ações referentes a EA em datas comemorativas, e, principalmente, na continuidade da temática no decorrer de todo o ano letivo.

A sétima pergunta, questionava acerca da opinião do aluno quanto a necessidade do tema ser trabalhado com mais frequência, sendo constatado que em ambas as escolas $94 \%$ dos alunos responderam de forma afirmativa, que a Educação Ambiental deveria ser trabalhada com mais frequência no espaço escolar. Baum e Povaluk (2012) em seus estudos também constataram que os alunos gostariam que as aulas de EA fossem mais frequentes e alegaram que isto comprova que os estudantes estão preocupados em estudar e debater em sala, em conjunto com seus colegas e professores a seriedade de preservar o ambiente.

A próxima pergunta tratava acerca da realização, nos colégios analisados, de eventos, palestras ou cursos voltados para Educação Ambiental sendo que em ambos os colégios a resposta positiva representou a maior

Revbea, São Paulo, V. 11, № 5: 123-138, 2016. 
fração, 85\%. Sobre esse tema, Medeiros, Ribeiro e Ferreira (2011) alegam que nos colégios públicos, além das dificuldades frequentemente encontradas ao se trabalhar com $E A$, há um agravante, a situação é mais precária devido à baixa quantidade de recursos, o que acaba dificultando a promoção de atividades extracurriculares (como palestras, oficinas, cursos) aos alunos.

$\mathrm{Na}$ penúltima pergunta feita aos alunos foi solicitado avaliassem o desempenho da escola e professores quanto à aplicação da Educação Ambiental para os alunos em: muito bom, bom, regular, fraco, muito fraco.

No Colégio A $41 \%$ dos alunos consideraram bom, $37 \%$ muito bom, $20 \%$ regular, enquanto as opções fraco e muito fraco foram responsáveis por $1 \%$ das respostas, cada. Já no Colégio B 34\% dos alunos avaliaram como regular, $31 \%$ bom, $25 \%$ muito bom, $9 \%$ muito fraco e $1 \%$ fraco.

A última pergunta questionava os alunos sobre a importância da introdução da Educação Ambiental como uma nova disciplina curricular. Nos dois colégios analisados, $99 \%$ dos alunos responderam de forma positiva, acreditando ser importante introduzir a EA como uma nova disciplina na grade curricular. É de grande importância a dispersão dos conteúdos que envolvem a Educação Ambiental, principalmente no ambiente escolar. Assim, a Educação Ambiental como disciplina curricular teria por finalidade ganhar espaço, visibilidade e materiais didáticos específicos (FOEPEL; MOURA, 2014).

\section{Análise das respostas fornecidas pelos professores}

A primeira pergunta do questionário aplicado aos professores fazia referência acerca da importância de se tratar acerca de meio ambiente. Nos dois Colégios analisados, todos os professores responderam que sim, que consideram importante falar sobre meio ambiente. É importante que os professores tenham essa conscientização da importância de se falar sobre meio ambiente, Silva et al (2012) os professores são os responsáveis por fazer a relação entre a sensibilização e a aquisição de conhecimento pelos alunos, mobilizando-os para as dificuldades ambientais existentes no seu cotidiano.

A segunda pergunta aborda quais disciplinas o professor acredita que deveria ser abordado o tema Educação Ambiental (Figuras 5 e 6). 


\section{Para você, em quais disciplinas deveria ser abordado o tema Educação Ambiental?}

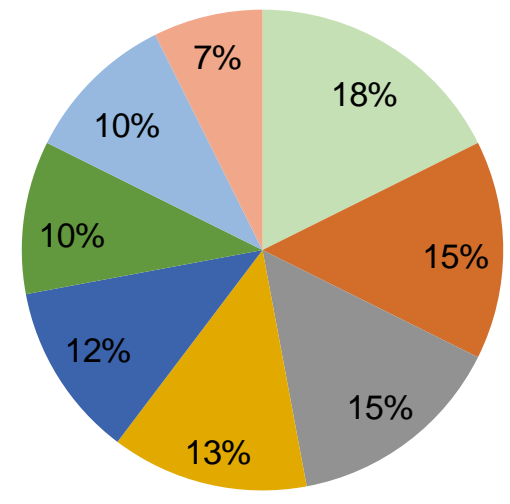

Geografia

- História

Arte

- Português

- Ed. Física

- Matemática

- Inglês

- Religião

Figura 5: Avaliação dos professores do Colégio A sobre quais disciplinas deve ser abordado o tema EA.

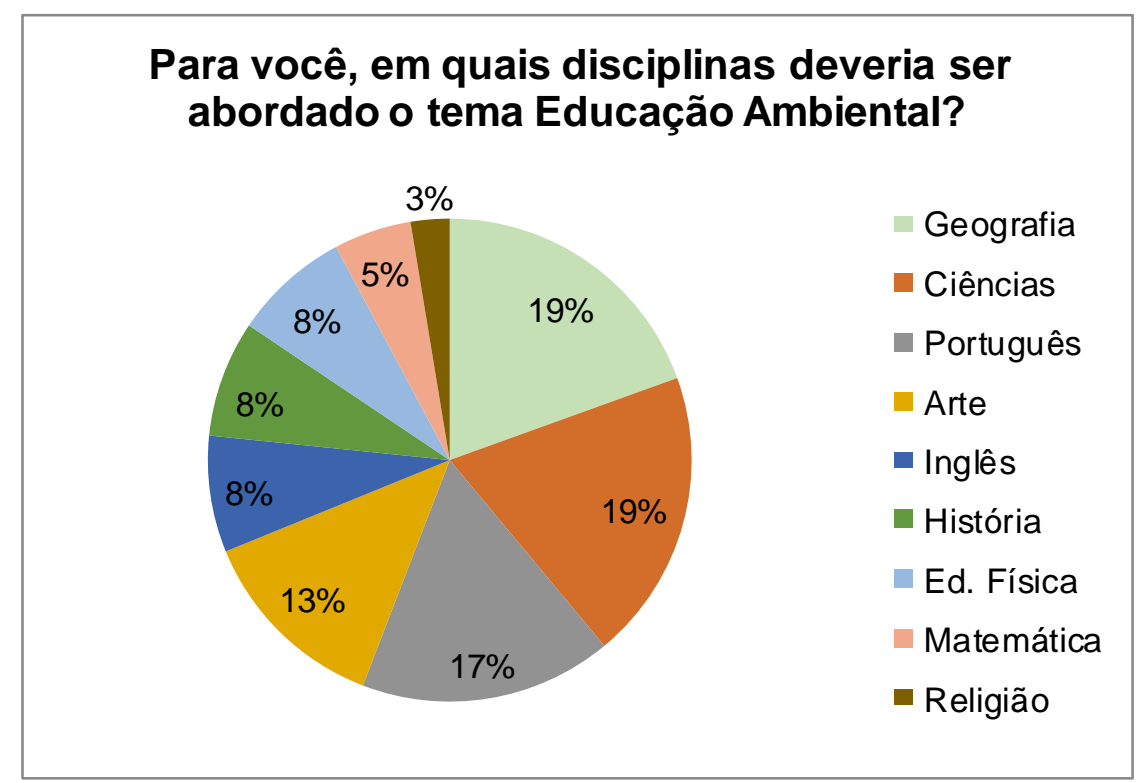

Figura 6: Avaliação dos professores do Colégio A sobre quais disciplinas deve ser abordado o tema EA.

A partir da análise das respostas, observa-se que houveram semelhanças e divergências nas respostas dos professores dos dois colégios. Nos dois colégios as disciplinas mais votadas foram Ciências e Geografia, respectivamente. No Colégio $A$, a terceira disciplina mais votada foi História e Arte, empatadas com $10 \%$ cada. Seguidas pelas disciplinas de: Português, Educação Física, Inglês, Matemática e Religião. Já no colégio B, a mais votada foi Português, seguida pela disciplina de arte. As disciplinas de Inglês, História 
e Educação Física foram responsáveis por $6 \%$ dos votos cada. As disciplinas menos votadas foram Matemática e Religião.

A próxima pergunta era se o professor considerava importante a introdução da Educação Ambiental como uma nova disciplina curricular. No Colégio A $73 \%$ dos professores consideram importante a introdução da EA como disciplina curricular, no Colégio B essa porcentagem foi de $88 \%$. Para Bernardes e Pietro (2010, p. 177) frente à problemática ambiental observada na sociedade, torna-se indispensável a EA como componente escolar, pois, "sua inclusão, como disciplina, poderá produzir resultados mais efetivos para a tomada de consciência sobre a necessidade de preservação do meio ambiente ou do desenvolvimento sustentável".

A quarta pergunta questionava sobre a realização de cursos voltados à prática da $E A$, no Colégio $A 53 \%$ dos professores alegaram não terem realizado cursos enquanto no Colégio $B$ esse valor foi ainda maior, sendo representado por $65 \%$. Sobre esse assunto, Mello Montes e Lima (2009, p. 50) tendo em vista que o processo educativo "possa contribuir para a melhoria da qualidade de vida, e por ser a escola, o espaço adequado para trabalhar a relação ambiente homem-sociedade", faz-se imprescindível discutir sobre as práticas pedagógicas, bem como, a realização de cursos, para que sejam possíveis reflexões acerca dos assuntos ambientais.

A próxima pergunta questionou sobre a facilidade da aplicação da temática ambiental na disciplina. No Colégio A 93\% responderam que consideram fácil aplicar, no colégio Jardim Independente esta resposta foi representada por $76 \%$. Posteriormente, perguntou aos professores se estes trabalham a EA em suas disciplinas, no Colégio A $67 \%$ alegou trabalhar a EA em sala de aula enquanto no Colégio B este valor foi de $71 \%$. Diante destes dois últimos resultados, é importante que os professores se capacitem a fim de serem de desenvolver atividades para tornar possível a interdisciplinaridade. Para que esta aconteça, segundo é preciso que as disciplinas notifiquem entre si, um modo de desenvolver trabalhos em sala de aula, para que a temática seja trabalhada em diferentes disciplinas (BALBINO; OLIVEIRA, 2014).

Em caso de respostas afirmativa na última pergunta, solicitou, então que os professores marcassem os principais temas abordados (Figuras 7 e 8 , próxima página).

Nos dois colégios analisados, apesar de divergências nas porcentagens constatadas, verificou-se que os assuntos mais trabalhados são: Aquecimento Global e Desmatamento. No Colégio A, a sequência foi: Ecologia e Água (17\% cada), Resíduos Sólidos (4\%) e Outro, sem justificar, com $31 \%$ do total cada. Já no Colégio B a sequência foi: Água (23\%), Ecologia (10\%) e Outro, sem justificar (3\%). Nenhum professor do Colégio B afirmou trabalhar o tema resíduos sólidos. 


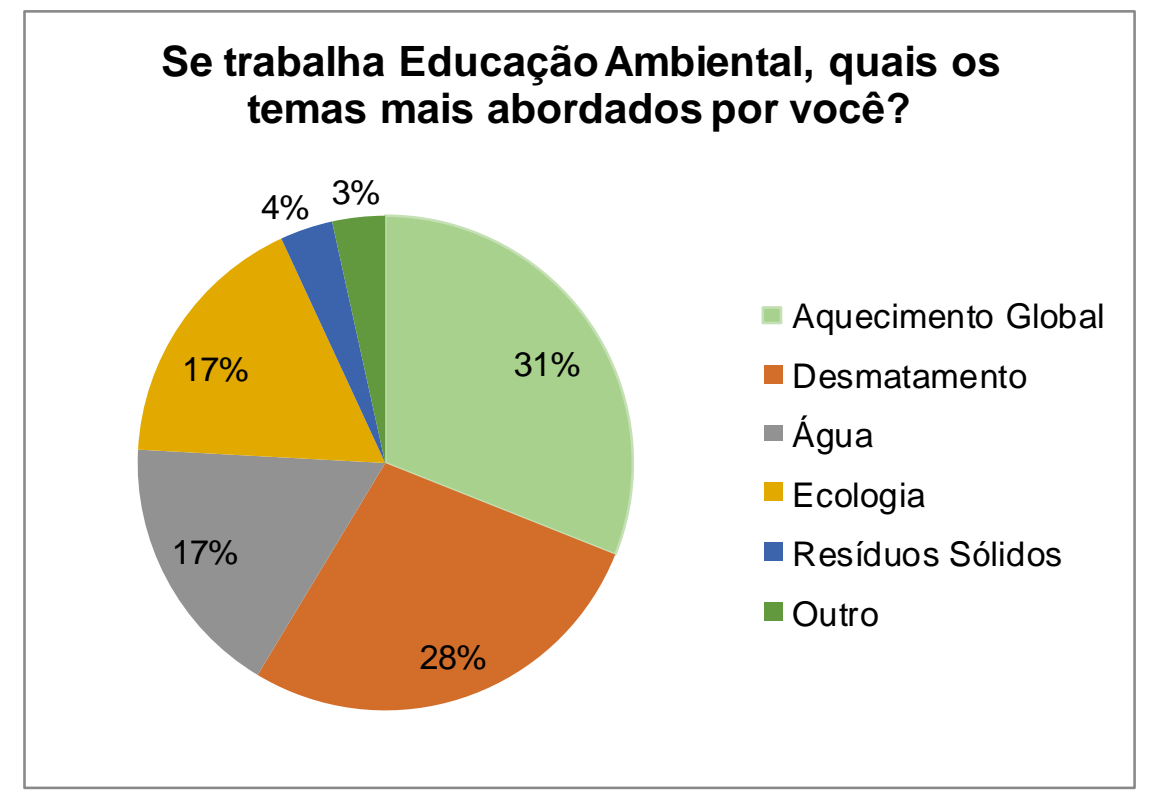

Figura 7: Resposta dos professores do Colégio A sobre quais temas trabalham em sala.

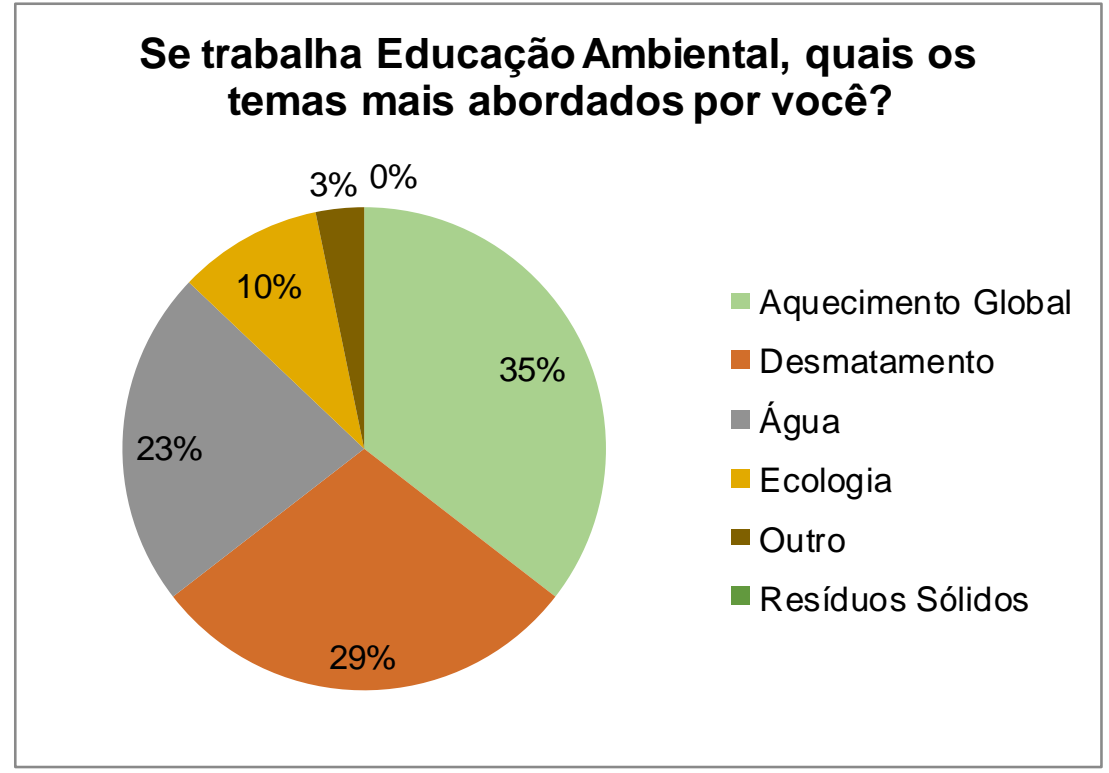

Figura 8: Resposta dos professores do Colégio B sobre quais temas trabalham em sala.

Para Silva (s/d) os principais temas sobre Educação Ambiental há se trabalhar com o ensino fundamental são: Desmatamento, poluição do ar e da água, aquecimento global e exploração desequilibrada dos recursos naturais estão entre os tópicos abordados na escola. Ainda ressalta que anteriormente à exibição dos tópicos aos alunos é importante que os professores tenham uma afinidade com a temática para transmitir segurança aos alunos.

A sétima questão foi sobre o desenvolvimento de atividades práticas voltadas à Educação Ambiental em sua disciplina. Nos dois colégios analisados, $73 \%$ dos professores alegaram não ter realizado atividade prática 
sobre EA em sala. Para Telles et al (2002) o professor precisa passar uma mensagem que chame a atenção dos alunos, e uma das melhores formas de se realizar isso é a partir da realização de práticas. Assim, seria interessante uma maior frequência na realização de práticas sobre EA nos dois colégios analisados.

A oitava pergunta questionou aos professores sobre a frequência com que a Educação Ambiental é trabalhada em sua escola. No Colégio A $47 \%$ dos professores afirmaram que é trabalhada durante todo o ano letivo, $46 \%$ apenas na Semana do Meio Ambiente e 7\% negou haver a prática de se trabalhar EA no ambiente escolar. Já no Colégio B $71 \%$ dos professores afirmaram que é trabalhada durante todo 0 ano letivo, $29 \%$ apenas na Semana do Meio Ambiente enquanto nenhum alegou não haver o hábito de se trabalhar EA na escola. Conforme citado anteriormente, sabe-se que há dificuldades na prática de EA nos ambientes escolares, porém, é preciso que sejam desenvolvidas atividades de forma continuada a fim de garantir a sensibilização os alunos e da comunidade escolar.

A décima pergunta faz referência quanto à opinião do professor sobre trabalhar a EA com maior frequência, em ambos os colégios a resposta positiva teve maior porcentagem, sendo que no Colégio $A$ foi de $93 \%$ e no Colégio $B$ foi $88 \%$. Baum e Pavolak (2012) em sua pesquisa constataram que, apesar de não serem todos os professores que gostariam que a EA fosse mais trabalhada, os alunos acreditam ser essencial trabalhar de modo mais frequente a temática em sala de aula.

A próxima pergunta questionou a forma com a qual o professor acompanha notícias relacionadas ao Meio Ambiente e a Educação Ambiental. Apesar da divergência nas respostas, nos dois colégios analisados, segundo os professores, as formas mais comuns de acesso a notícias sobre esta temática são: Internet, televisão e revistas. No Colégio $A$ as formas menos frequentes de acesso à temática em questão são Livros e Congressos, com $5 \%$ cada, outros meios (3\%). No Colégio $B$ as formas menos frequentes de acesso à temática em questão são Livros (9\%), Congressos, com $7 \%$, outros meios (5\%). Nenhum professor respondeu que não acompanha este assunto.

Bovo (2007) acredita ser essencial que o professor se concentre em manter-se informado sobre as questões ambientais da atualidade e que possam surgir, por meio dos diversos meios disponíveis, mas também é importante que este seja capaz de relacionar os aspectos atuais com fatos históricos.

A pergunta número 12 questionou os professores quanto ao seu preparo para atuar como um educador ambiental. Nos dois colégios analisados $65 \%$ dos professores alegaram não estarem preparados para tal função. Rita Mendonça em entrevista ao site da Revista Escola ao ser questionada se o professor está preparado para ser um educador ambiental, respondeu que o professor está "especialmente preparado, porque é um educador. Mas, se ele 
quer se engajar na questão ambiental, deve começar pensando na sua vida, no seu comportamento e na sua relação com o próprio corpo e com a natureza" (REVISTA ESCOLA, s/d).

Ao serem questionados sobre as oportunidades para aperfeiçoamento do professor em Educação Ambiental, nos dois colégios 93\% dos professores responderam que não há oportunidade. Baum e Povaluk (2012) em seu estudo na cidade de Rio Negrinho - SC constataram que 60\% dos docentes responderam que há oportunidade para cursos de aperfeiçoamento na área de Educação Ambiental, sendo principalmente cursos. Este fato mostra uma diferença nas realidades das duas cidades, sendo que Sarandi não possibilita tais oportunidades, as quais são de extrema importância para que o professor seja capaz de sensibilizar os alunos sobre os aspectos ambientais.

A penúltima pergunta era sobre a realização de eventos, palestras ou cursos voltados para Educação Ambiental na escola. Apesar da divergência das porcentagens apresentadas, em ambos os colégios analisados a maior parte respondeu que não são realizados, sendo que no Colégio $A$, a porcentagem foi de $93 \%$ enquanto no Colégio B foi de $88 \%$. Acerca disso, Baum e Povaluk (2012) em pesquisa sugerem a teoria educacional, um padrão que transversalize a Educação Ambiental no ensino fundamental, devendo ser considerado a realização de palestras, cursos e outros eventos para a comunidade escolar, e principalmente, voltado ao aperfeiçoamento dos professores.

A última pergunta questionou como o professor avalia o desempenho da sua escola e de seus companheiros de profissão quanto à aplicação da Educação Ambiental para os alunos. Apesar de divergências nas porcentagens, em ambos os colégios mais da metade dos professores acredita que o desempenho é avaliado como bom. No Colégio A $54 \%$ dos professores avaliaram o desempenho como bom, 33\% como regular e 13\% como muito. Já no Colégio B, $59 \%$ classificaram como bom, $23 \%$ regular e $18 \%$ bom.

\section{Conclusões}

A Educação Ambiental é um pressuposto básico para qualquer ação que vise o desenvolvimento sustentável, já que, é impossível viabilizar a implantação de qualquer processo ambiental independentemente da Educação Ambiental. Ficou evidente o valor da educação à sociedade para que este aja seguindo preceitos de responsabilidade e conscientização, garantindo a conservação do ambiente, tanto para o presente quanto às futuras gerações.

Foi possível constatar que a Educação Ambiental deve ser uma política pública prioritária na busca pelo desenvolvimento sustentável, bem como ser considerada um instrumento de gestão ambiental importante para que esta visão do desenvolvimento sustentável seja materializada. Quando aplicada em ações nos colégios, já que esta é tida como uma das formas mais práticas de serem efetivadas, favorecendo a sensibilização de toda a comunidade escolar. 
Ao considerar os questionários respondidos pelos alunos dos Colégios analisados, foi possível constatar que os alunos dos dois colégios entendem a importância de trabalhar a Educação Ambiental. Observa-se que mesmo abordando diferentes temas da Educação Ambiental em todo o decorrer do ano letivo, os alunos acham necessário trabalhar com mais frequência o tema e que é importante à introdução de uma nova disciplina na grade curricular direcionada à Educação Ambiental.

Além disso, verifica-se que mesmo a Educação Ambiental sendo abordada dentro de sala, não há realização de cursos, eventos ou palestras nas escolas como forma de incentivo. Segundo a maioria dos alunos de ambos os colégios o desempenho das escolas e professores se dividem entre regular, bom e muito bom. Tendo por base os questionários dos professores, contatouse que mesmo aplicando diversos tópicos da Educação Ambiental em sala e sabendo da importância da mesma, a maioria dos professores de ambos os colégios nunca fizeram cursos voltados para a prática de Educação Ambiental.

Assim como os alunos, os professores acham necessário a introdução de uma disciplina na grade curricular voltada para a Educação Ambiental, porém a maioria não se considera preparada para atuar como educador ambiental. Também foi possível observar que não há oportunidade para aperfeiçoamento dos professores e que não há a realização de eventos, cursos ou palestras voltadas para a Educação Ambiental nos colégios estudados. Mesmo com as dificuldades encontradas para trabalhar a Educação Ambiental nos colégios, os professores avaliam o desempenho das escolas e de seus companheiros em sua maioria como bom.

Após a realização deste estudo, entende-se que há a necessidade de aperfeiçoamento por parte dos professores para que a Educação Ambiental seja trabalhada de forma mais intensa e com maior qualidade nas escolas. A realização de cursos, palestras e eventos voltados tanto para alunos quanto para professores é de grande importância para que isto ocorra. Deve-se capacitar os professores e funcionários das escolas para que a Educação Ambiental possa ser trabalhada, ou até mesmo ser introduzida como uma nova disciplina na grade curricular.

\section{Referências}

ARARUNA, L.B. Investigando ações de Educação Ambiental no currículo escolar. 2009. 145 f. Dissertação (Mestrado em Educação) - Universidade Federal do Rio de Janeiro, Rio de Janeiro, 2009.

BALBINO, M.L.C.; OLIVEIRA, L.L.V. A interdisciplinaridade na Educação Ambiental e sua aplicação no ensino superior. Âmbito Jurídico, Rio Grande, XVII, n. 123, abr 2014.

BAUM, M.; POVALUK, M. A Educação Ambiental nas escolas públicas municipais de Rio Negrinho, SC. Revista Saúde e Meio Ambiente, v.1, n.1, 2012. 
BERNARDES, M.B.J.; PRIETO, E.C. Educação Ambiental: disciplina versus tema transversal. Revista Eletrônica do Mestrado em Educação Ambiental, v. 24, jan./jul., 2010.

BRASIL. Lei no 9.795, de 27 de abril de 1999. Dispõe sobre a Educação Ambiental, institui a Política Nacional de Educação Ambiental e dá outras providências. Disponível em http://www.planalto.gov.br/ccivil 03/leis/L9795.htm>. Acesso em: 21 maio 2015.

FADANNI, D.; MASSOLA, U. Abordagem da Educação Ambiental nos Anos Iniciais em Três Escolas do Município de Palmitos. 2010. 48f. Projeto de Pesquisa (Licenciatura em Ciências Biológicas)-UnoChapecó, Chapecó, 2010.

GIL, A.C. Métodos e Técnicas de Pesquisa Social. 6 ed. São Paulo: Editora Atlas, 2002.

LINS, R.B.; LISOSKI, L.A. Educação Ambiental na escola o trabalho desenvolvido por professores de um colégio do interior do Paraná. Olhar de professor, Ponta Grossa, v. 13, n. 1, p. 171-184, 2010.

MEDEIROS, M.C.S.; RIBEIRO, M.C.M.; FERREIRA, C.M.A. Meio ambiente e Educação Ambiental nas escolas públicas. Âmbito Jurídico, Rio Grande, v. 14, n. 92, set. 2011.

MELLO, A.D.; MONTES, S.R.; LIMA, L. Educação Ambiental em curso de formação continuada para docentes do ensino básico - Uberlândia (MG). Em extensão, Uberlândia, v. 8. n. 1, p. 48-59, jan./jul. 2009.

NARCIZO, K.R.S. Uma análise sobre a importância de trabalhar Educação Ambiental nas escolas. Revista Eletrônica do Mestrado em Educação Ambiental, v. 22, jan./jul, 2009.

PIOVESANA, A. Educação Ambiental e Poder público: O desenvolvimento sustentável em Alvorada do Sul (PR). 2011. 23 p. Trabalho de Conclusão de Curso (Especialização em Gestão Pública) - Programa Nacional de Formação em Administração Pública - Universidade Estadual de Maringá, Maringá, 2011.

REIGOTA, M.A.S. Ciência e Sustentabilidade: A contribuição da Educação Ambiental. Avaliação - Revista de Avaliação da Educação Superior, v. 12, n. 12, jun. 2007,p. 219-232.

REVISTA NOVA ESCOLA. Rita Mendonça "O educador ambiental ensina por suas atitudes". s/d. Disponível em: $<$ http://revistaescola.abril.com.br/ciencias/fundamentos/rita-mendoncaeducador-ambiental-ensina-suas-atitudes-426107.shtml>. Acesso: 08/11/15.

SANTOS, Luana Magda Muniz dos. A importância de práticas de ensino criativas na Educação Ambiental. In: Anais do VII ENCONTRO NACIONAL DE PESQUISA EM EDUCAÇÃO EM CIÊNCIAS, Florianópolis, 8 nov. 2009. Disponível em: <http://posgrad.fae.ufmg.br/posgrad/viienpec/pdfs/101.pdf>. Acesso em: 08 nov. 2015. 
SILVA, L. et al. Como apresentar o tema meio ambiente aos alunos do ensino fundamental. 2012. Disponível em: <http://www.cpt.com.br/cursoseducacao-infantil/artigos/como-apresentar-o-tema-meio-ambiente-a-alunos-doensino-fundamental >. Acesso em: 08 nov. 2015.

VIEIRA, V.A. As tipologias, variações e características da pesquisa de marketing. Curitiba, Revista da FAE, v.5, p.65-70, jan./abr. 2002.

YIN, R.K. Estudo de Caso: planejamento e métodos. $4^{\circ}$ ed. Porto Alegre: Bookman, 2010.

\section{APÊNDICE A - Questionário aplicado aos alunos}

1. Você acha importante trabalhar sobre Educação Ambiental? ( ) Sim ( ) Não

2 - Seus professores abordam o tema Educação Ambiental em alguma disciplina? ( ) Sim ( ) Não

3 - Se a resposta acima for sim, marque abaixo em quais disciplinas é abordado o tema Educação Ambiental.
( ) Português
( ) Inglês
( ) Matemática ( ) Geografia
( ) História
( ) Arte
( ) Ed. Física ( ) Religião
( ) Ciências

4 - Quais os temas mais discutidos pelos professores quando falam sobre Educação Ambiental?
( ) Ecologia
( ) Resíduos Sólidos
( ) Água
( ) Aquecimento Global
( ) Desmatamento
( ) Outro

5 - Seus professores já desenvolveram alguma atividade prática voltada para a Educação Ambiental? ( ) Sim ( ) Não

6 - A Educação Ambiental é trabalhada na sua escola somente na semana do meio ambiente ou durante o ano todo? ( ) Semana do meio ambiente ( ) Ano todo ( ) Não é trabalhada

7 - Em sua opinião, a Educação Ambiental deveria ser trabalhada com mais frequência na sua escola? ( ) Sim ( ) Não

8 - A sua escola realiza eventos, palestras ou cursos voltados para Educação Ambiental?

$\begin{array}{ll}\text { ( ) } \operatorname{Sim} & \text { ( ) Não }\end{array}$

9 - No geral, como você avalia o desempenho da sua escola e seus professores quanto à aplicação da Educação Ambiental para os alunos?
( )Muito Bom
( ) Bom
( )Muito Fraco
( ) Regular
( ) Fraco

$$
\text { ( Muito Fraco }
$$

10 - Você considera importante a introdução da Educação Ambiental como uma nova disciplina curricular? ( ) Sim

( ) Não 


\section{APÊNDICE B - Questionário aplicado aos professores}

1 - Em sua opinião, falar sobre Meio Ambiente é importante? ( ) Sim ( ) Não

2 - Para você, em quais disciplinas deveria ser abordado o tema Educação Ambiental?
( ) Português
( ) Inglês
( ) Arte
( ) Matemática ( ) Geografia
( ) História
( ) Ed. Física
( ) Religião
( ) Ciências

3 - Você considera importante a introdução da Educação Ambiental como uma nova disciplina curricular? ( ) Sim ( ) Não

4 - Você já fez algum curso voltado para a prática de Educação Ambiental? （ ) Sim （ ) Não

5 - Você acha fácil aplicar a questão ambiental na sua disciplina? ( ) Sim ( ) Não

6 - Você trabalha Educação Ambiental em sua disciplina? ( ) Sim （ ) Não

7 - Se trabalha Educação Ambiental, quais os temas mais abordados por você?
( ) Ecologia
( ) Resíduos Sólidos
( ) Água
( ) Aquecimento Global
( ) Desmatamento
( ) Outro

8 - Você já desenvolveu alguma atividade prática voltada para a de Educação Ambiental em sua disciplina? ( ) Sim ( ) Não

9 - A Educação Ambiental é trabalhada na sua escola somente na semana do meio ambiente ou durante o ano todo? ( ) Semana do meio ambiente ( ) Ano todo ( ) Não é trabalhada

10 - Em sua opinião, a Educação Ambiental deveria ser trabalhada com mais frequência na sua escola? ( ) Sim ( ) Não

11 - Como você acompanha notícias relacionadas ao Meio Ambiente e a Educação Ambiental?
( )Cursos, congressos, etc
( ) Revistas
( ) Livros
( ) Internet
( ) Televisão
( ) Outros

( ) Não acompanho

12 - Você se considera preparado para atuar como um educador ambiental?

$\begin{array}{ll}\text { ( ) Sim ( ) Não } & \end{array}$

13 - São oferecidas oportunidades para aperfeiçoamento do professor em Educação Ambiental? ( ) Sim ( ) Não

14 - A sua escola realiza eventos, palestras ou cursos voltados para Educação Ambiental?

$\begin{array}{lll}\text { ( ) } \operatorname{Sim} & \text { ( ) Não }\end{array}$

15 - No geral, como você avalia o desempenho da sua escola e seus companheiros de profissão quanto à aplicação da Educação Ambiental para os alunos?
( )Muito Bom
( ) Bom
( ) Fraco
( )Muito Fraco
( ) Regular 